\section{РОЗДІЛ 1 \\ ТЕОРЕТИКО-ПРАКТИЧНІ ПРОБЛЕМИ \\ ПЕДАГОГІКИ ВИЩОЇ ШКОЛИ}

УДК 378.115:377.1:678.1

Тетяна Васенок

\title{
ПІДГОТОВКА МАЙБУТНІХ ФАХІВЦІВ ШВЕЙНОЇ ГАЛУЗІ ДО ПРОЕКТНО-КОНСТРУКТОРСЬКОЇ ДІЯЛЬНОСТІ
}

Васенок Т. Підготовка майбутніх фахівців швейної галузі до проектноконструкторської діяльності.

У статті проаналізовано зміст навчального матеріалу 3 проектноконструкторської підготовки майбутніх фахівців швейної галузі в різних навчальних закладах країни. Запропоновано методику конструювання жіночого одягу для навчального процесу i процесу виготовлення одягу як засіб підвищення якості професійної підготовки майбутніх фахівців галузі.

Ключові слова: фахівці швейної галузі, проектно-конструкторська діяльність, методика конструювання жіночого одягу.

Васенок Т. Подготовка будущих специалистов швейной отрасли к проектноконструкторской деятельности.

В статье проанализировано содержание учебного материала по проектноконструкторской подготовке будущих специалистов швейной отрасли в разных учебных заведениях страны. Предложена методика конструирования женской одежды для учебного процесса и процесса изготовления одежды как способ повышения качества профессиональной подготовки будущих специалистов отрасли.

Ключевые слова: специалисты швейной отрасли, проектно-конструкторская деятельность, методика конструирования женской одежды.

Vasenok T. Preparing future specialists of sewing industry for the projective-designing activity.

Educational design training content of the future sewing specialists in different educational establishments was analyzed. Women's clothes design methods for educational process and clothes' design process as a means of future specialists' professional training quality increasing are suggested.

Key words: sewing specialists, designing activity, women's clothes design methods.

Процеси глобалізації освітнього простору, що відбуваються у світі, містять великий потенціал для розвитку професійної освіти в нашій країні, роблять нагальним завдання підготовки фахівця, здатного до проектування власної діяльності в різних соціокультурних ситуаціях, готового виробляти особливу стратегію професійного мислення, поведінки й діяльності.

Вітчизняна система підготовки висококваліфікованих фахівців має бути приведена у відповідність до сучасних потреб економіки країни та потреб у кваліфікованих кадрах усіх професійних сфер. Суспільство зацікавлене в тому, щоб громадяни були здатні самостійно, активно діяти, приймати рішення, гнучко адаптуватися до умов життя, що стрімко змінюються.

Посилення особистісної відповідальності громадян за свою долю, за життєве та 
професійне самовизначення, за власне благополуччя вимагає від молоді правильного вибору майбутньої професії якомога раніше. Допомогти школяреві не тільки обрати «свою», а й психологічно та практично підготуватися до праці мають шкільні предмети «Трудове навчання» $\mathrm{i}$ «Технології». Їх метою $є$ підготовка учнів до трудової діяльності в різних сферах виробництва та домашньому господарюванні, ознайомлення 3 різними професіями та технологічними процесами й обладнанням, залучення учнів до основних видів проектно-конструкторських і технологічних робіт.

Отже, для багатьох майбутніх фахівців підготовка до професійної діяльності розпочинається ще у шкільному віці на уроках трудового навчання й у профільних класах загальноосвітніх навчальних закладів, а продовжується у процесі здобуття освіти у професійно-технічних закладах і вищій школі та в подальшій трудовій діяльності. Саме в цей час у майбутнього фахівця закладаються основи тих якостей професіонала, 3 якими він увійде в нову для нього атмосферу діяльності, де відбуватиметься його подальший розвиток як професійної особистості.

Зростання вимог до якості швейних виробів і підготовки кадрів для певної галузі у XXI столітті вимагає глибоких професійних знань і творчого підходу до справи від фахівців модної індустрії різних кваліфікацій та етапів виготовлення одягу. Однією 3 умов професійної успішності майбутнього фахівця $\epsilon$ здібність до проектноконструкторської діяльності, що надає творчого характеру обраній професії, визначає iї інноваційний потенціал.

Вимоги до професійної діяльності майбутніх фахівців постійно змінюються, доповнюються новими. Змінюються уявлення про пріоритетні завдання освіти i змінюються підходи до підготовки фахівців, з'являються нові особистісно-діяльнісні моделі навчання, спрямовані на усвідомлення мотивів діяльності, на розвиток пізнавальних можливостей і творчого потенціалу.

Отже, проблема підготовки молоді до майбутньої проектно-конструкторської діяльності у швейній галузі легкої промисловості нині стає актуальною для системи освіти, оскільки вона відповідає потребам підготовки фахівця нового типу.

Проблема формування технологічно грамотної особистості, підготовленої до життя й активної трудової діяльності в умовах сучасного високотехнологічного, інформаційного суспільства, розглядалася рядом науковців. Вивченням професійної підготовки майбутніх фахівців опікувалися Н. Алік, В. Безрукова, Т. Дев'ятьярова, Е. Ільїна, Е. Зебра, О. Кириченко, О. Коваленко, О. Марущак, В. Радкевич, Л. Тархан, Е. Ткаченко, Е. Шматко та ін. У працях розглядалися різні аспекти професійно-технічної та інженерно-педагогічної освіти, вдосконалення професійної підготовки майбутніх фахівців, зокрема фахівців швейної галузі. Підготовку фахівців із залученням до проектної діяльності досліджували М. Бондаренко, О. Дубасенюк, С. Ізбаш, Л. Кондратова, І. Кольцовська, Л. Лісіна, В. Шеховцова, Г. Шкільова та ін.

Професійна діяльність майбутніх фахівців швейної галузі різних кваліфікацій тісно пов'язана 3 інженерною діяльністю. Інженерна діяльність фахівця, як відомо, пов'язана 3 розробленням технічних об'єктів - із їх проектуванням. Інженерна діяльність фахівця швейної галузі пов'язана 3 проектуванням швейних виробів, що $є$ неможливим без застосування трудомісткого проектного процесу з конструювання одягу.

Значну увагу підготовці фахівців швейної галузі із залученням до проектноконструкторської діяльності приділяли такі дослідники, як Л. Агошков, С. Коблякова, М. Колосніченко, Г. Кононенко, К. Процик, А. Славінська, А. Сушан, В. Щербань та iH.

Одним із основних компонентів сучасних педагогічних технологій формування 
особистості майбутнього фахівця на будь-якому етапі професійної підготовки (шкільна, професійно-технічна або вища професійна) є зміст навчання. Основним складником змісту навчання проектуванню одягу є зміст навчального матеріалу.

Тому метою статmі є аналіз змісту навчального матеріалу з проектування, який використовується в навчальному або навчально-виробничому процесі підготовки майбутніх фахівців швейної галузі на різних етапах професійної підготовки та в сучасних технологічних процесах проектування і виробництва одягу.

Проектування і виготовлення швейних виробів має кілька виробничих процесів. Основними процесами, що визначають якість одягу на стадії домашинного проектування, $є$ моделювання й конструювання. Під час конструювання одягу, коли розробляється креслення конструкції, дуже важливо обрати правильне рішення форми виробу одним із конструктивних прийомів і методів технологічного оброблення або тим та іншим прийомом одночсано.

Конструювання одягу, як найважливіша частина проектування виробів, передбачає використання різних методик конструювання. Отже, цілком закономірним нашим завданням постає необхідність проаналізувати сучасні методики конструювання швейних виробів i обрати найоптимальнішу для професійної проектно-конструкторської діяльності майбутніх фахівців швейної галузі.

Виготовленням одягу люди займалися з глибокої давнини. За всіх часів він був і залишається особливою «візиткою» людини, яка визначає не тільки зовнішній вигляд людини, iіi соціальний і культурний статус, але й естетичний рівень, професію, вік i навіть настрій.

На сучасному етапі розвитку промисловості України швейна галузь знаходиться в дуже критичному стані: зменшується кількість великих підприємств 3 виготовлення одягу, і навпаки, збільшується кількість підприємств індивідуального та невеликих підприємств масового виготовлення одягу.

Реалізація завдань сьогодення 3 підвищення якості одягу й розширення асортименту виробів багато в чому визначається якістю підготовки фахівців легкої промисловості.

За даними дослідження робітників швейної галузі, починаючи з 90 років XX століття, набула масового характеру. Однак з 2000 року спостерігається ії суттєве скорочення. Якщо в 20002001 навчальному році випуск кравців у межах України становив 17071 осіб, то випуск 2006-2007 становив уже 9728 осіб, що майже на 43\% менше. Це явище дослідник пояснює об'єктивними й суб'єктивними причинами, а саме: низьким рівнем адаптації випускників ПТНЗ швейного профілю до вимог конкретного робочого місця, а також відсутністю в молоді мотивації до оволодіння робітничими професіями швейної галузі через складні умови праці, низьку заробітну плату.

Із давніх часів одяг є дзеркалом, у якому відображається вся історія людства. Нині одяг не втратив своєї актуальності. Сьогодення доводить, що людина XXI століття не готова відмовитися від одягу.

Зростання обсягу проектних робіт в умовах сучасного ринку особливо гостро актуалізує завдання скорочення термінів і підвищення якості процесу проектування. Конструювання розглядається як один із основних процесів проектування одягу. Це складний творчий процес, у ході якого доводиться розв'язувати низку завдань художнього та технічного характеру. Від точності і якості робіт на цьому етапі проектування залежить якість готового виробу.

Якість швейного виробу прямо залежить від рівня підготовки фахівця, від його 
професійного вміння отримувати 3 плоскої тканини та інших матеріалів, що використовуються під час проектування одягу, просторової форми виробу i розв'язання зворотнього завдання - побудова розгорток деталей одягу, заданого ескізом або зразком моделі. Результатом успішного оволодіння навчальним матеріалом $\epsilon$ отримані креслення - розгортки деталей виробу (конструктивної основи), які після їх складання мають забезпечити заплановану форму виробу та іï відповідність розмірам і формі тіла людини.

У кожну епоху по-різному розв'язували проблему передавання багатовікового досвіду зі «створення» одягу наступним поколінням.

Результати нашого дослідження довели, що більшість школярів (87\%) ще у процесі навчання втрачають інтерес до конструювання швейних виробів (при загальному збереженні інтересу і бажанні шити одяг) через складність розрахунків і «невстигання будувати за вчителем».

Навчання конструювання швейних виробів у професійно-технічних навчальних закладах відбувається за допомогою різних методик конструювання. Аналогічна ситуація спостерігається у вищих навчальних закладах України. Проектуванню (а саме конструюванню) швейних виробів у вишах навчають традиційно: використовують різні методики конструювання з ручним методом побудови креслень конструкцій. Вибір методик конструювання пояснюється їх використанням у ПТНЗ швейного профілю, рекомендаціями Будинків моди та іншими галузевими рекомендаціями. Опитування викладачів ВНЗ, власний досвід роботи засвідчує, що в навчальній i професійно-практичній діяльності фахівців швейної галузі певні методики конструювання виправдовують себе тільки в окремих ситуаціях. Відсутність єдиної методики конструювання, яка могла б задовольнити вимоги освіти й виробництва країни, спричиняє безліч проблем у педагогічній і швейній галузях через незадовільний кінцевий результат - швейний виріб, який недостатньо задовольняє вимоги споживачів. Тільки великий практичний досвід роботи, професіоналізм фахівця допомагає правильно обрати методику конструювання для навчання своїх учнів і для побудови креслення основи виробу під час промислового (масового) або індивідуального виготовлення одягу.

У другій половині XX століття 3'явилася велика кількість систем і методик конструювання одягу. Кожна 3 них науково обгрунтована, ураховувє закономірності змінюваності розмірів тіла людини, але час від часу не влаштовує фахівців швейної галузі. Початківцю інколи дуже важко розібратися в наявних системах та методиках конструювання одягу і ще важче зробити правильний вибір для застосування під час проектування швейних виробів.

Більшість наукових праць швейної галузі присвячено жіночим фігурам. Як показали сучасні антропометричні дослідження, вони характеризуються великим розмаїттям форм та складністю геометрії поверхні (Т. Цимбал).

У ході нашого дослідження вивченню підлягало понад 70 вітчизняних i зарубіжних методик конструювання жіночих швейних виробів легкого асортименту, які пропонувалися різними авторами протягом останніх кількох десятиліть (майже 60 років). В основу аналізу покладено кількість необхідних вимірів фігури для побудови креслення основи виробу за певною методикою конструювання; графічні та математичні способи знаходження місцерозташування ліній i точок побудови креслення; графічні способи побудови, математичні розрахунки розхилу та довжини виточок - одного 3 основних конструктивних елементів одягу; структура розрахункових формул. 
Проведений нами аналіз побудови креслень конструкцій поясних і плечових виробів засвідчив складність та проблемність останніх. Саме тому нашу увагу присвячено вдосконаленню методики конструювання жіночих плечових виробів легкого асортименту.

Дослідження змісту і процесу навчання, змісту навчального матеріалу майбутніх фахівців швейної галузі різних навчальних закладів країни сприяло розробленню безрозрахункової методики конструювання.

Розкриємо сутність розробленого нами змісту методики конструювання жіночого плечового виробу як найпростішого варіанта побудови креслення основи сукні на типову фігуру з використанням констант для визначеного розміру і зросту. Перший варіант розробленої методики конструювання складався 39 розмірозростів, на які можна було виконати побудову креслення основи виробу без математичних розрахунків [1]. Для визначення певного розмірозросту достатньо знати два виміри фігури: зріст і півобхват грудей III (розмір). Послідовність побудови креслення замість розрахункових формул передбачала таблички 3 константами і поетапні рисунки побудови креслення. Додатково до методики конструювання внесено різні види і форми контролю побудови креслення.

Уперше безрозрахункова методика конструювання була використана в навчальному процесі загальноосвітніх навчальних закладів різних типів на уроках трудового навчання для навчання учнів 3 низьким рівнем попередньої підготовки до сприймання навчального матеріалу, з уповільненою швидкістю перебігу розумових процесів і наявністю індивідуальних пізнавальних інтересів.

Розроблена методика конструювання дозволяла значно скоротити час побудови креслення і повністю виключити помилки у процесі математичних розрахунків та своєчасно виправити помилки у кресленні.

Застосування розробленої методики конструювання сприяло вихованню в учнів наполегливості, працелюбності і віри в свої сили. Це допомогло їм виконати навчальну роботу і відчути задоволення від іiі виконання. Оволодіння навчальним матеріалом, виконання програмового завдання 3 трудової підготовки супроводжувалося позитивними змінами в мотиваційній сфері. Засвоєння основ конструювання швейних виробів відбувалося відповідно до здібностей, навчальнопізнавальних можливостей, інтересів учнів тощо. Суттєво підвищилася успішність учнів класу (на 12-19\%) та ефективність уроків з конструювання швейних виробів.

Позитивні результати впровадження безрозрахункової методики конструювання в навчальний процес сприяли розширенню кількості розмірозростів до 15 . Навчальний посібник [2], розрахований на підготовку майбутніх учителів технологічної освіти, пропонує побудову креслення основи сукні на типову фігуру підлітків найбільш застребуваних 15 розмірозростів. Необхідні уточнення на конкретну фігуру можна вносити в креслення під час перевірки побудови креслення, а також у виріб під час проведення I примірки. Ще 24 базові конструкції проміжних розмірозростів можна отримати за допомогою градації лекал.

Використання розробленої методики конструювання жіночого плечового одягу в навчальному процесі загальноосвітніх та вищих навчальних закладів дозволило за короткий час побудувати креслення основи виробу напівприлеглого силуету (додавання на вільне облягання 4 см) з урахуванням висоти плечової накладки в моделі. Конструкція жіночого одягу враховувала індивідуальні антропологічні особливості фігури, наближеної до умовно-пропорційної, без використання багаточисельних мірок або стандартних вимірів фігури і розрахунків. 
Третє тисячоліття характеризується посиленням вимог до професійнопрактичної підготовки майбутніх фахівців швейної галузі, необхідністю іiі наближення до міжнародних стандартів якості, скорочення обсягів некваліфікованої та малокваліфікованої праці у процесі проектування і виготовлення одягу, постійним зростанням конкуренції на ринку праці та готової продукції.

Очевидним стало те, що для підготовки майбутніх кваліфікованих робітників швейної галузі і викладачів професійно-технічних навчальних закладів швейного профілю безрозрахункової методики конструювання 315 розмірозростів недостатньо. Роботу із збільшення кількості розмірозростів у методиці конструювання довелося продовжити.

За даними ОСТ 17-326-81 [4], основними параметрами жіночого одягу є розмір, зріст і повнота. Цим стандартом встановлено 137 типових жіночих фігур, на які пропонується здійснювати виготовлення одягу під час промислового виробництва. Індивідуальне виготовлення швейних виробів передбачає зняття вимірів фігури 3 кожного конкретного замовника одягу.

Серед основних параметрів жіночого одягу ми обрали 2, що визначають певний розмірозріст людини, виокремили серед встановлених типових фігур 333 найбільш затребувані розмірозрости. Зріст обрано від $146 \mathrm{~cm}$ до $176 \mathrm{~cm} 3$ інтервалом $1 \mathrm{cm,}$ розмір - від $84 \mathrm{~cm}$ до $136 \mathrm{~cm} 3$ інтервалом $4 \mathrm{~cm}$. Для зручності користування розробленою методикою конструювання пропонується скорочений запис побудови креслення, де побудова базисної сітки здійснюється за 11 кроків, а побудова креслення спинки або переду - за 7. Кожний із трьох етапів побудови креслення основи виробу (побудова базисної сітки, спинки, переду) супроводжується рисунками.

Побудова креслень конструкцій за безрозрахунковою методикою конструювання жіночого плечового одягу дозволяє за короткий час побудувати креслення основи виробу напівприлеглого силуету та вивільнити час на другий етап проектування одягу - моделювання. Користувачам залишається творча частина роботи.

Сучасний одяг є результатом багатовікового досвіду людини, одним 3 його найстародавніших винаходів, складовою частиною матеріальної та духовної культури суспільства. XXI століття - це століття технічного прогресу. Це час, коли одяг збагачується новими конструктивними рішеннями як в цілому, так і окремих деталей одягу. Тому ще більш актуальною постає проблема вдосконалення технічного етапу конструювання одягу, який передбачає розроблення креслень конструкцій деталей та вузлів виробу. Під упливом змінюваних вимог до нових моделей одягу, прагнення створити конструкцію одягу сучасних форм 3 урахуванням антропологічної характеристики споживача і властивостей матеріалів відбуваються подальші якісні зміни конструктивного рішення одягу.

Унаслідок зміни методології і технології проектування, переміщення аспектів 3 трудомістких проектних процедур на наукомісткі процедури на часі постає впровадження нових методик конструювання, здатних полегшити, спростити та прискорити процес проектування виробу.

Спроможність швидко отримати конструкцію виробу дозволить одержати значний економічний ефект завдяки підвищенню продуктивності праці, скороченню витрат на проектування, раціональнішому використанню сировини й робочої сили, підвищити інженерний рівень процесу проектування моделей одягу 3 більш ефективним використанням кадрів, а також вивільнити час для творчої проектної діяльності [5]. 
Реалізувати соціальне замовлення суспільства має найновіша безрозрахункова методика конструювання швейних виробів.

Використання запропонованої методики конструювання жіночих плечових виробів у процесі професійної проектно-конструкторської підготовки майбутніх фахівців швейної галузі під час проектування i виготовлення одягу сприяло підвищенню інтересу до занять, рівня оволодіння конструкторськими знаннями i вміннями, якісному та швидкому виготовленню виробів.

Розвиток комп'ютерної техніки наприкінці XX століття сприяв переходу від традиційних ручних методів проектування до нових комп'ютерних систем розроблення нових моделей одягу. Використання найновіших технологій, зокрема комп'ютерних, у галузі інженерії має перевести професійну діяльність фахівця швейної галузі на новий, більш високий якісний рівень.

Задля підвищення якості виконання проектних робіт, перспективним постає поява доступних вітчизняних систем автоматизованого проектування одягу. Упровадження САПРО в навчально-виробничий процес професійної підготовки майбутніх фахівців швейної галузі у професійно-технічних навчальних закладах, коледжах та вищих навчальних закладах дозволить підготувати сучасного працівника «нового типу».

Розроблена нами методика конструювання жіночого плечового одягу має широкі можливості іiі застосування фахівцями швейної галузі під час проектування одягу. Застосування комп'ютерної програми методики конструювання дозволяє отримати креслення основи виробу в автоматизованому режимі.

\section{Література}

1. Васенок Т. М. Конструювання 3 елементами моделювання плечового виробу [методичні рекомендації]. 8 клас / Тетяна Михайлівна Васенок. - Глухів : РВВ ГДПІ, 1999. - 72 с. 2. Васенок Т. М. Основи конструювання жіночого одягу: [навч. посіб.] / Тетяна Михайлівна Васенок. - Глухів : РВВ ГДПУ, 2005. - 100 с. 3. Гриценок І. А. Педагогічні умови організації виробничого навчання учнів ПТНЗ швейного профілю: дис. ... канд. пед. наук: 13.00.04 / Гриценок Інна Анатоліївна. - К., 2007. - 305 с. 4. Изделия швейные, трикотажные, меховые. Типовые фигуры женщин. Размерные признаки для проектирования одежды: ОСТ 17-326 - 81. - М. : ЦНИИИТЭИлегпром, 1981. - 109 с. 5. Сушан А. Т. Інженерне проектування швейних виробів: [навч. посіб.] / Алла Тимофіївна Сушан. - К. : Арістей, 2008. - 172 с.

УДК 370.98.23

Надія Вовк

\section{ОСОБЛИВОСТІ СТРУКТУРНИХ ЕЛЕМЕНТІВ ФОРМУВАННЯ СПОЖИВЧОЇ КУЛЬТУРИ МАЙБУТНІХ УЧИТЕЛІВ ТЕХНОЛОГІЇ}

Вовк Н. В. Особливості структурних елементів формування споживчої культури майбутніх учителів технології.

У статті подано аналіз концепту «споживання», досліджено генезу поняття «споживча культура», «культура споживання», визначено складники споживчої культури. Культура споживання майбутнього вчителя має динамічний характер, розвиток здійснюється на основі задоволення потреб у професійній діяльності, культурі, особистісних цінностях. Споживча культура надає набори зразків споживання, виборів, цінностей і смаків, які допомагають людині орієнтуватися в соціальному просторі та отримати якісну освіту. 